\title{
Jury Decision Making: Is the Devil in Journal of Criminal Justice and Law the Details? Observations of a Criminal Justice Professor from Inside the Jury Room
}

\section{Julie Kiernan Coon ${ }^{\prime}$}

"Most of what goes on during deliberations in the 150,000-plus jury trials each year in the United States is shrouded in mystery."

Jury decision making and the process of deliberation continue to be of interest to criminal justice practitioners and academics. When I received a summons for jury duty, I was told by more than one colleague that the chances of an academic being selected to serve on a jury were slim. I wondered if having a PhD in criminal justice might serve as my "get out of jury duty free" card. When I was ultimately selected to serve as a juror in a criminal case, it was apparent that my degree did not prohibit me from serving, nor was it always obvious who would be dismissed from the panel.

My profession aside, my family connections to law enforcement (my father is a retired prosecutor and my grandfather was a New York City police sergeant) seemingly would make me an unlikely candidate for a jury. After being selected to serve on a jury in a felony assault case, I was somewhat intrigued by what was to come, yet at the same time in disbelief that the defense attorney had not struck me from the pool. Ultimately, the judge selected me as the jury foreperson, which allowed me to help guide the deliberation process.

To put the experience into context, this paper will first present highlights from the research literature about jury decision making. Second, observations about the jury selection process, along with details of the case, will be shared, including the stories told by the victim and the defendant. These two "down and out" men had similar histories in terms of unemployment, homelessness, and alcoholism. Yet they were perceived in drastically different ways by members of the jury. Finally, I will share what occurred in the

${ }^{1}$ Cochran, D. Q. (2015). Malcom Gladwell and the art of trial advocacy: Getting the jury to the tipping point. American Journal of Trial Advocacy, 38(2), 335-376.

\footnotetext{
' School of Justice Studies, Roger Williams University, Bristol, Rhode Island, USA.

Corresponding Author:

Julie Kiernan Coon, School of Justice Studies, Roger Williams University, One Old Ferry Road, Bristol, RI 02809, USA

E-mail: jcoon@rwu.edu
} 
jury room and how what I observed connects to the research literature. It is hoped that both large-scale research projects and single case studies such as this will be informative for court officials and academics.

\section{Research on Jury Decision Making}

It is well documented that the vast majority of criminal cases in the United States that proceed through the system result in plea bargaining rather than trial. Nevertheless, the jury trial remains a critical component of our system of justice. According to Devine (2012, p. 6), an estimated 154,000 jury trials, nearly half of them trials for felony crimes, took place in 2006. Further, Devine (p. 8) claims that as of 2011, about 1,500 studies of juries had been published. For criminal cases that end in a trial, it is understood that the criminal charge is serious, the process is important, and the stakes are high on both sides.

\section{Who Is Being Studied?}

Scholars generally agree that the most significant early research was The Chicago Jury Project, highlighted in the work of Kalven and Zeisel (1966) comparing judicial and jury decisions for the same cases. This work is widely cited throughout the jury literature, with one major finding being that judges and juries were mostly in agreement in their verdicts, although exceptions were hardly rare. Later research attempted to replicate some aspects of this study comparing judge-jury agreement. For example, Eisenberg et al. (2005, p. 173) found a high rate of judge-jury verdict agreement (above 70\%), although they explored in greater depth the role of the strength of evidence in decision making. Further, Gastwirth and Sinclair (2004) analyzed Kalven and Zeisel's original data with more sophisticated models and found that disagreement between the judge and jury was more complex. Specifically, they found that disagreements depended on the relationships among a variety of factors, including seriousness of the crime, strength of the evidence, quality of the defense attorney, and prior record of the defendant (Gastwirth and Sinclair, 2004, p. 183). Later major studies include the Capital Jury Project and research conducted by the National Center for State Courts (as cited by Devine, Buddenbaum, Houp, Stolle, and Studebaker, 2007).

Although the importance of juries in our system of criminal justice is widely acknowledged, jury research that is based on the decision-making processes of mock jurors is often criticized as unrepresentative of actual jury deliberations (for a thorough review see Nunez, McCrea, and Culhane, 2011). It is clear that the research on jury deliberations has taken a number of different approaches. Bornstein (1999) argues that the numerous challenges encountered in studying actual jurors have resulted in the use of mock juries as the primary means of studying jury decision making. Nunez et al. also discuss how much of the research on jury decision making involves mock jurors, and they question whether using mock jurors is the best method to understand the process of deliberations. Further, they state that the research on mock juries has often been conducted with college students (who represent a convenience sample for academics studying jury decision making). Devine, Krouse, Cavanaugh, and Basora (2016) summarized the issue of reliance on college student samples: "Overreliance on studies of undergraduate students making noninteractive decisions about a fictional trial runs the risk of providing a misleading picture of how real juries make decisions. There is a need for more field research that complements and extends the laboratory research with mock jurors" (Devine et al., p. 671). 
Some investigators have attempted to expand the research on mock juries by including residents of the larger community (Nunez et al., 2011). Interestingly, however, Breau and Brook (2007) compared mock jury studies that relied on students with studies that included nonstudents as jury members. They found that type of juror did not tend to alter the verdict.

\section{Models of Decision Making}

Devine et al. (2016, p. 670) summarized much of the research on mock juries and identified three possible variables to explain jury verdicts: evidentiary factors, extra-evidentiary factors, and the deliberation process. Evidentiary factors are aspects of the factual information presented during a trial, including the type, quality, and amount. Extraevidentiary factors are those that should not be considered in decision making, such as the race and gender of the defendant. The deliberation process includes the style of the discussion that takes place, the individuals or subgroups that offer dissenting views, the number of votes taken, etc. Devine et al. (2016) found that the strength of the evidence had the greatest influence on participants, but that extra-evidentiary and deliberation factors might also influence verdicts. Earlier work by Devine et al. (2007, p. 300) found that juries did well in some aspects of deliberation but not others. Specifically, juries understood the instructions and reviewed the evidence, but deliberations did not always allow all members of the jury to be heard, and factions within the jury often developed. Recently, researchers have also begun to examine the role of implicit bias in jury decision making (see Elek and Hannaford-Agor, 2015).

According to Devine (2012), there are many different approaches to examining decision making, including some that focus on individual jurors and others that attempt to explain how juries as a group come to a consensus in their verdicts. Two of the models discussed by Devine seem consistent with my own observations and experience. One such model is the stochastic model, which Devine (2012, p. 25) explains as follows: "Jurors are assumed to sequentially process the evidence they encounter at trial, while extracting the evaluative implications along the way, but at some point a critical event occurs that halts the decision process." Devine (2012) further explains that the "critical event" ranges from an important piece of evidence to more individual perceptions or feelings, such as being overwhelmed by the amount of information presented or simply feeling tired.

Pennington and Hastie (1992, p. 190) claimed, "The story organization facilitates evidence comprehension and enables jurors to reach a predeliberation verdict decision." This is the model that seemed most consistent with my experience. As later described by Devine (2012, p. 26), the story model is based on the assumption that jurors develop their own narratives to make sense of evidence presented at trial that may be confusing, disjointed, and difficult to fully understand. Jurors must decide what information will be included as part of their own version of events, and what information will be disregarded (Devine, 2012). As I will discuss, the development of narratives among jury members was inevitable, but the prosecutor and defense attorney also played critical roles in how these stories were formed.

\section{The Case: Felony Assault}

\section{Jury Selection Process}

Many people appeared highly motivated to avoid being selected. Some jurors spoke of family obligations (such as a prior commitment to help a family member move to Rhode 
Island) that they felt should allow them to be dismissed from jury duty. As part of the voir dire process, we were asked a series of questions, including whether any of us had been convicted of a crime (one potential juror was removed because of an embezzlement conviction) and whether we had prior experiences with victimization (most of us had been victims of property crime). We were also asked about our past experiences with the police because there would be testimony from a patrol officer and detective.

When asked about encounters with the police, one juror shared a story about being pulled over by a police officer for running a red light. He stated he had informed the officer that the light was broken and would not turn green. The juror claimed the officer replied that the light was not broken and issued a citation. He concluded his story by announcing that all police were liars and he would believe the word of anyone over a cop. It seemed that this person was determined to be struck and was successful in achieving that goal.

We were also asked a series of questions about family and occupation. One potential juror was a retired police officer but had subsequently done investigative work for a public defender's office. The defense attorney asked him whether he felt he could be fair and impartial given his law enforcement background. The juror's response was, "Five years ago, I don't think I could have been fair, but now that I have been away from the job for a while, I have mellowed out considerably. I think doing 5 to 6 hours of yoga a day has definitely helped." The attorney responded, "Well, you do realize that if you are selected for this case, you may not have time for 5 to 6 hours of yoga a day." The defense attorney demonstrated his sense of humor and did not strike him.

The defense attorney also attempted to play a "gotcha game" with seemingly no winners or losers. He asked us, the potential jury members, to raise our hands if we had asked ourselves, "I wonder what this guy did?" Only one person raised her hand. The defense attorney then responded, "You do realize that the burden is on the state to prove my client guilty beyond a reasonable doubt. He does not have to speak at all in his defense." Her response was, "Oh yeah, I know, but I think it is natural to wonder." Despite her apparent bias against the defendant, and to my surprise, the defense attorney did not strike her from the jury pool.

\section{Two Stories in a Nutshell ${ }^{2}$}

The victim's story. ${ }^{3}$ Tom claimed he met the defendant, Robert, on the streets of Providence during "Occupy Providence" in the fall of 2011. According to Tom, the event was basically a 5-day drinking party for him, Robert, and others. After so many days of being intoxicated, Robert realized he must have lost his job as a short-order cook, and he asked Tom if he could crash at his place for a while. Tom felt sorry for Robert and agreed to let him live with him (along with another roommate named Dan, whom Tom thought of as a son, although they were not related). Robert lived at Tom's apartment for several months before the night of the incident. During those months, Tom claimed that Robert did not work, cook, clean, or contribute to the household in any way. Tom said Robert simply sat around the house watching crime-related television shows, ate Tom's food, and drank Tom's liquor.

\footnotetext{
2 The trial included testimony from the first police officer on the scene, a detective, the victim, and the defendant. This article focuses primarily on the stories told by the victim and the defendant.

${ }^{3}$ All names have been changed.
} 
The night of the incident, Tom stated they were all drinking heavily and that he had made dinner. He said that Robert was going on a rant about his son and ex-wife and was generally angry at the world. Tom was sitting in a recliner in the living room. Robert went into the kitchen and came out with a knife. Robert attempted to stab Tom in the chest, which Tom says he blocked with his right hand. (Note: The medical report and photos showed that Tom had a cut on his left hand. In addition, the detective had taken photos of Tom's abdomen showing numerous cuts and wounds, but it was never explained how he had sustained those wounds.) After Tom attempted to block the knife, Robert stabbed him in the arm (photos were shown of blood on the kitchen floor, and a deep-looking cut on Tom's forearm). Tom ran to the kitchen to grab a towel to stop the bleeding and stated he had bled profusely because his blood was thinned by all the alcohol he had consumed.

The defendant's story. ${ }^{4}$ According to Robert, the first time he met Tom was when he had woken up in Tom's apartment with a hangover. Robert realized that he must have lost his job and couldn't really remember the last time he had shown up to work. He had previously been living in the garage at his brother's house, and he thought his brother would be mad that he had lost his job as a short-order cook. Robert also thought his brother probably wouldn't let him return because Robert was an alcoholic and drinking again.

Robert claimed he did not live with Tom for free. Although Robert acknowledged that he was unemployed, he said that on day 1 Tom had asked him if he received food stamps. When Robert said yes, Tom said he could stay there as long as he had food stamps because they could sell the food stamps and use the money to buy "booze." Robert claimed that while he lived there, he did some cooking and cleaning and brought the garbage to the curb for the entire apartment building.

The night of the incident, Robert claimed that Tom was having one of his "tizzy fits." Tom was upset that Robert and Dan had refused to eat the dinner he had made. Robert and Dan were still drinking, and they never ate dinner until they were done drinking. As part of this fit, Tom said he was throwing the dinner away, but in actuality, had left the meal outside the apartment in the hallway.

Later that evening, Robert had finished drinking (he admitted to having three "giant, monster-size 7-Eleven cups," each of which was half vodka and half water) and was hungry. He looked around the apartment for the food Tom had made and did not see it in the trash. Robert then looked in the hallway outside the apartment and saw the meal in a crockpot on the floor. He brought it back into the apartment, grabbed a plate and utensils, and went to the living room to eat it.

Robert sat down and added salt and pepper to the meal. According to Robert, when Tom saw him adding salt and pepper he felt insulted and became enraged. Tom told Robert, "Get out, get out of my house." Robert claimed that Tom often told him and Dan to leave, and he thought that if he cleaned up, Tom would calm down after a while.

Robert got up from the recliner and picked up his plate, fork, and knife to bring them into the kitchen, at which point Tom grabbed him by the shoulder from behind. Robert stated he was twisted around, both Tom and Robert fell, and that is how Tom was stabbed. They were drunk and had recently moved the furniture around in the living room, which contributed to the confusion and the fall. Although Robert admitted that he did cut Tom, he claimed it was an accident. Robert further stated that if he had wanted to stab Tom intentionally he could have, but he had no reason to do so. The other roommate, Dan, did

${ }^{4}$ All names have been changed. 
not directly witness the incident but was in the apartment at the time and called 911. After the incident, Robert knew it "looked bad," and because Tom was screaming, "You stabbed me, you stabbed me," he waited around to tell the police his side of the story.

\section{Inside the Jury Room}

We had spent many hours together in the jury room but were unable to discuss the case until deliberations began on day 3. Going up the stairs to the jury room on day 2, one juror stated, "I've heard enough." This statement was made after he had heard only from the victim, patrol officer, and detective, and I was not sure what his comment meant. When we first entered the room to deliberate, it was chaotic, with the dominant personalities all talking at once and clearly excited to "get it done." As the jury foreperson, though, I felt responsible for making sure that each juror had the opportunity to share his or her thoughts about the testimony and other evidence, and for promoting an orderly discussion.

The likeability factor. It was clear early in the deliberations that many jurors had already formed strong opinions, often about matters that were irrelevant to the facts of the case. For example, one juror commented that although she didn't really like the prosecutor, she liked her outfits. Another juror commented that she didn't like the detective because she perceived him to be smirking when the defendant was testifying. Discussions regarding the likeability of everyone involved in the case seemed inescapable.

It was especially evident that many jurors had a strong dislike for the victim and distrusted him. One juror commented that the victim was "shady," and she could envision him throwing a "tizzy fit," as the defendant had claimed. I was surprised by how much the jury seemed to like and sympathize with the defendant but appeared to have nothing but contempt for the victim. Both the victim and the defendant had made poor choices in their lives, suffered from addiction and health problems, and looked much older than their years. A number of jurors commented that the victim did not make eye contact, which to them meant he was lying. The defendant, on the other hand, looked directly at us (several jurors noted that he seemed to make more eye contact with female jurors), which many jurors believed was an indication he was telling the truth. My response to these statements was, "So you don't think someone can look at you and lie to your face?" yet these types of comments seemed to be disregarded.

Another issue that was problematic for the victim was his prior criminal record. The victim's criminal history of welfare fraud seemed to provide an easy excuse for many jurors to dismiss his testimony as entirely false. The fact that we did not hear anything to suggest that the defendant had a criminal record boosted his credibility with most of the jurors. I reminded them that Tom's criminal history did not make him immune to being a victim, yet the jurors appeared to want to make sense of the story pretty quickly in a good guy/bad guy fashion. They also seemed uninterested when I pointed out that those with criminal records are often themselves at higher risk for victimization.

Missing from the story. A number of missing pieces in the case were problematic during the deliberations. First, the absence of Dan (the younger roommate) was unexplained, and this was a bit perplexing for the jury. There was a belief that if Dan's pseudo-dad had really been stabbed intentionally, Dan would have testified in the case. Additionally, the photograph taken by the detective showing numerous stab wounds on the victim's stomach was a problematic piece of evidence. We had been told that when Tom was making his statement at the police department after the incident, he had complained to the detective about his stomach hurting. The detective asked if he could lift his shirt and 
subsequently documented numerous wounds all over Tom's abdomen. There was nothing in the victim's testimony to suggest he had injuries inflicted by Robert other than the cuts on his hand and forearm. The lack of explanation for how these wounds occurred seemed strange and created additional confusion about what had occurred on the night of the incident.

\section{The Verdict and Meeting With the Judge}

The defendant's testimony did not convince me that he had stabbed the victim by accident, but the burden was not on the defense. Much of the victim's story did not ring true either. My perception was that both men seemed to be less than entirely truthful, were omitting important information, or possibly did not even really remember what had happened during the incident. After 2 hours of deliberating, we reached a verdict of not guilty. Although there was much about the case we did not agree upon, we did agree that the state had not proved its case beyond a reasonable doubt.

After the trial was over, the judge met with us. She would not say if she agreed with our decision, but she did want to thank us for our service and see if we had questions. We were told that the defendant did indeed have a criminal record, but that the prosecutor and defense attorney had agreed not to use this information because the offense had occurred many years ago. We also learned that both the prosecution and the defense had agreed not to reveal certain aspects of Tom and Robert's relationship, which, when paired with some information we learned during the trial, implied they had a sexual relationship. Further, we were informed that the victim had a long history of anger issues and was currently in counseling. Lastly, when we asked the judge about the whereabouts of roommate Dan, she revealed that he was supposed to testify in the case but could not be located and was presumed homeless again.

\section{Lessons From the Jury Room}

Gladwell (2002, p. 132) wrote, "The lesson of stickiness is the same. There is a simple way to package information that, under the right circumstances, can make it irresistible. All you have to do is find it."

It is important that each side tells a story that makes sense to jurors. The stories told by the victim and the defendant were both problematic. Numerous details and omissions and "gut instincts" were factors in the jury's decision in this case. Tom's version of the incident was difficult to believe because he was essentially saying that Robert was mad at other people and with no warning came out of the kitchen and tried to stab Tom. More importantly, that any person, let alone someone with a criminal history of welfare fraud, would allow someone to live in his home, eat his food, drink his liquor, watch television all day, and not contribute to the household in any way made no sense. People get some sort of benefit from their relationships with others. Although we did not know the extent of what the victim got from the defendant, a basic understanding of human interactions suggested that there was more to their relationship than was revealed during the trial.

The prosecutor and defense attorney apparently had numerous agreements about what information would not be revealed during the trial. A problem with these omissions was that neither story seemed plausible. When neither story is "sticky," as described by Gladwell (2002), jurors will form their own narratives in a manner that makes sense to them, but that likely will be far different from the story the prosecution and defense thought they were telling. Further, the gaps in the story can contribute to jurors forming their own 
stories before hearing all of the evidence. Prosecutors and defense attorneys should consider how these gaps will likely affect jurors' perceptions early in the trial.

The lack of eye contact contributed to discrediting the victim, whereas the defendant's consistent eye contact contributed to a sense of his trustworthiness on the part of many members of the jury. It is unknown if the prosecutor stressed to the victim the importance of making eye contact, but his unwillingness or inability to look at the jury damaged his credibility with several jurors. Further, the absence of information about the defendant's criminal record during the trial led some jurors to assume wrongly that he did not have a criminal past. It appeared that this omission put the defendant in an advantageous position with some members of the jury.

Cochran (2015, pp. 371-372) noted, "People have an unconscious aversion to being persuaded and resist when they feel someone is trying to sell something. The solution to this dilemma is to realize that people like their own ideas and, as a result, your goal in your opening statement is to tell your story in such a way that they want you to win."

Although the prosecutor repeatedly emphasized in her opening and closing statements that the victim had "baggage," jurors may hold beliefs that victims and offenders are mutually exclusive groups. Further, as suggested by Cochran (2015), people do not want to feel as if someone is trying to convince them. The prosecutor's repeated statements regarding the victim's troubled past may have contributed to the jury feeling that she was trying too hard to sell the victim's version of events. Perhaps instead of emphasizing the victim's past, the prosecutor should have more generally made the jury aware that offenders often become victims.

Both the prosecutor and the defense attorney appeared to be trying hard to build rapport with the jury, yet I was somewhat surprised when most jurors connected better with the defense attorney. He clearly demonstrated a good sense of humor yet seemed less experienced, less articulate, and less passionate in his arguments than the prosecutor. The jury seemed to relate to him better, possibly because his performance was somewhat awkward at times and so may have seemed less rehearsed.

How the courtroom participants were dressed was noticed and discussed by some jurors. As stated earlier, the prosecutor's outfits were very much appreciated by one juror. The prosecutor was very well dressed, but this did not seem to contribute to her likeability. In fact, her extremely polished appearance and speech may have made her less relatable to this jury. The defense attorney was not as stylish, nor as eloquent, but his dress and oratory abilities were never mentioned. It also made me wonder if this critique of the prosecutor was also because she was female. Regardless of the reasons for the apparent favoritism for the defense, it seems important that both sides adapt to the jury they have in front of them. Prosecutors and defense attorneys should continually look for cues about how the jury is responding to their case but should also be aware of how the jury perceives them and be willing to modify their approach accordingly.

The trial at times strongly resembled theater, with the performance of many of the courtroom participants judged throughout the trial. As stated earlier, one juror commented that she didn't like the detective because she perceived him to be smirking when the defendant was testifying. I did not share this perception and thought perhaps his expressions reflected his disbelief in the defendant's version of events. In addition, the victim's lack of eye contact was associated with lying, at least according to some jurors. Attorneys should do their best to make sure that victims and witnesses understand they may be critically observed by the jury, both on and off the stand. 
Devine et al. (2007, p. 273) posed this essential question about the jury system: "What do criminal juries really do behind the closed door of the deliberation room? Is it what we hope and does it make a difference anyway?"

I had expected that I would feel a sense of satisfaction about the decision we made and that justice had been done, but I have yet to feel good about it. Although I feel it was the right verdict, the often petty and irrelevant comments made by my fellow jurors were discouraging. Many of these jurors had formed their narratives and seemed to have little to no interest in the deliberation process I tried to promote. It is hoped that this essay will serve as an example of what can happen behind the closed door of the jury room, and what factors may contribute to the development of jurors' narratives of the case. Much of what was said in the jury room did not seem to affect our decision, yet somehow it seems as if we should aspire to something better for this important part of our criminal justice process.

\section{Lessons for the Classroom}

Beyond the story itself, there have been ways of revisiting this experience with my students. Through active participation in the classroom, students can often better identify the inherent problems with the case, without simply hearing it in narrative form. Activities such as "semiscripted" mini mock trials based on the case appear to have piqued student interest in the criminal justice system. Students tend to ask more questions about the missing pieces of the story and sometimes wonder why the trial happened at all. Further, students have generally embraced the opportunity to assume the roles of the courtroom participants, and each side has made its case to the jury. While the jury deliberates, I do not provide any input or answer questions, but I enjoy observing what happens during their discussions. Most of the time, my student mock juries reach the same verdict as the actual jury but have not consistently focused on the same aspects of the case. There were many frustrating and disappointing aspects of jury duty. The ability to continue to reflect on my "time served," however, and create interactive classroom activities for my students has made me somewhat grateful for this (I hope) "once in a lifetime" experience.

\section{Declaration of Conflicting Interests}

The author declares no potential conflicts of interest with respect to the research, authorship, and/or publication of this article.

\section{Funding}

The author received no financial support with respect to the research, authorship, and/or publication of this article

\section{References}

Breau, D. L., \& Brook, B. (2007). "Mock" mock juries: A field experiment on the ecological validity of jury simulations." Law \& Psychology Review, 31, 77-92.

Bornstein, B. H. (1999). The ecological validity of jury simulations: Is the jury still out? Law and Human Behavior, 23(1), 75-91.

Cochran, D. Q. (2015). Malcom Gladwell and the art of trial advocacy: Getting the jury to the tipping point. American Journal of Trial Advocacy, 38(2), 335-376. 
Devine, D. J., Buddenbaum, J., Houp, S., Stolle, D. P., \& Studebaker, N. (2007). Deliberation quality: A preliminary examination in criminal juries. Journal of Empirical Legal Studies, 4(2), 273-303.

Devine, D. J. (2012). Jury decision making: The state of the science. New York, NY: New York University Press.

Devine, D. J., Krouse, P. C., Cavanaugh, C. M., \& Basora, J. C. (2016). Evidentiary, extraevidentiary, and deliberation process predictors of real jury verdicts. Law and Human Behavior, 40(6), 670-682.

Eisenberg, T., Hannaford-Agor, P. L., Hans, V. P., Waters, N. L., Munsterman, T., Schwab, S. J., \& Wells, M. T. (2005). Judge-jury agreement in criminal cases: A partial replication of Kalven and Zeisel's The American jury. Journal of Empirical Legal Studies, 2(1), 171-206.

Elek J. K., \& Hannaford, P. (2015). Implicit bias and the American juror. Court Review, 51, 116-121. Retrieved from http://www.ncscjurystudies.org/ /media/Microsites/Files/CJS/What\%20We\%20Do/Elek\%20\%20 Hannaford-Agor\%202015\%20\%20Implicit\%20bias\%20and\%20the\%20American\%20juror.ashx

Gastwirth, J. L., \& Sinclair, M. D. (2004). A re-examination of the 1966 Kalven-Zeisel study of judge-jury agreements and disagreements and their causes. Law, Probability and Risk, 3(3-4), 169-191.

Gladwell, M. (2002). The tipping point: How little things can make a big difference. New York, NY: Back Bay Books/Little, Brown and Company.

Kalven Jr., H., \& Zeisel, H. (1966). The American jury. Boston, MA: Little, Brown and Company.

Nunez, N., McCrea, S. M., \& Culhane, S. E. (2011). Jury decision making research: Are researchers focusing on the mouse and not the elephant in the room? Behavioral Sciences and the Law, 29, 439-451.

Pennington, N., \& Hastie, R (1992). Explaining the evidence: Tests of the story model for juror decision making. Journal of Personality and Social Psychology, 62(2), 189206.

\section{Author Biography}

Julie Kiernan Coon is an associate professor of criminal justice in the School of Justice Studies at Roger Williams University, Bristol, Rhode Island. She earned a BA degree in economics from the State University of New York at Albany, and MS and PhD degrees in criminal justice from the University of Cincinnati, Cincinnati, Ohio. She has published in the areas of policing, school security, and crime prevention. 